O.O. Kardasevich, $\mathrm{PhD}$, Assoc.Prof., V.V. Chichenin, PhD, Assoc.Prof., A.S. Hrytsayenko, Master

Odessa National Polytechnic University, 1 Shevchenko Ave., 65044 Odessa, Ukraine; e-mail: g.anastasiy90@gmail.com

EXERGY BALANCE AND EFFICIENCY

\title{
OF THE ABSORPTIVE AND ADSORPTIVE PROCESSES BY THE EXAMPLE OF DEAERATOR
}

\begin{abstract}
О.О. Кардасевич, В.В. Чиченін, А.С. Грицаєнко. Ексергетичний баланс і ефективність сорбційних і десорбційних процесів на прикладі деаератора. Робота присвячена оцінці ефективності хіміко-технологічних процесів на основі ексергетичного методу аналізу на прикладі процесів в деаераторі. Мета: Метою роботи є демонстрація особливостей застосування ексергетичного методу аналізу до сорбційних і десорбційних процесів на прикладі деаератора. Матеріали $\boldsymbol{i}$ методи: Перевагою ексергетичного методу $\epsilon$ врахування не лише кількості, але й якості потоків енергоресурсів і багатокомпонентних матеріальних потоків, які характеризують енергетичний баланс будь-якої енерготехнологічної системи. Складність ексергетичного аналізу апаратів з багатокомпонентними потоками полягає в тому, що основний технічний ефект процесу проявляється подвійно: в одному випадку основне завдання - отримати потік чистої води, в іншому випадку — потік концентрату. Для тих процесів, де основним завданням $\epsilon$ отримання чистої води, ексергетичний ефект проявляється в збільшенні ексергії цього потоку. У процесах, де основне завдання - згущення розчину, корисний ефект полягає в зростанні ексергії концентрату. Результати: Наочно і чисельно проілюстровано величини ексергетичних потоків, у тому числі й ексергії сорбції і десорбції газів, що характеризують хімічні й термічні перетворення в деаераторі. Показано надзвичайно низьку ефективність процесів видалення кисню в деаераторі з точки зору перетворень ексергії і можливість виявлення шляхів вдосконалення процесів видалення газів на основі ексергетичного методу. Розрахунок потоків термічної і фізико-хімічної ексергії засвідчує, що деаератор на $95 \%$ ефективний як теплообмінник і абсолютно неефективний як массообмінник $(0,071 \%)$. Дана методика дає можливість оцінювати хіміко-технологічні процеси, в яких відбувається розподіл компонентів i, отже, придатна не тільки для газових складових, але й для твердих.

Ключові слова: термічна ексергія, енергетичний баланс, деаерація, парціальний тиск, енергоресурси.
\end{abstract}

O.O. Kardasevich, V.V. Chichenin, A.S. Hrytsayenko. Exergy balance and efficiency of the absorptive and adsorptive processes by the example of deaerator. The work is devoted to assessing of the effectiveness of chemical-technological processes on the basis of exergy analysis method by the example of the processes in the deaerator. Aim: The aim of the work is to demonstrate the features of the application of exergy analysis method for sorption and desorption processes via example of the deaerator. Materials and Methods: The advantage of the exergy method is in the accounting not only the quantity but also the quality of energy flows and multicomponent material flows that characterize the energy balance of any power technology system that puts this method on the first place on their objectivity in comparison with traditional methods of thermodynamic analysis. Complexity of the exergy analysis devices with multi-component flows, where separation processes such as water solutions occur, is that the main technical effect of the process is shown in two ways: in one case, the major problem is to obtain clean water flow, and in another case to obtain the concentrate flow. For those processes, where the main objective is to obtain clean water, an exergy effect is manifested in the increase of the exergy flow. In processes where the main task is solution thickening the useful effect is in the growing of exergy concentrate. Results: The exergy flows value was illustrated numerically and graphically including exergy gases sorption and desorption that characterizing the chemical and thermal transformations in the deaerator. It is showing an extremely low efficiency of the processes of oxygen removing in the deaerator from the standpoint of transformation of exergy and the ability to identify ways to improve the processes of gases removing based on exergy method. Calculations of heat and physicchemical exergy flows indicate that the deaerator is effective as a heat exchanger $(95 \%)$, and absolutely no effective as mass exchanger $(0.071 \%)$. This technique makes it possible to evaluate the chemical-technological processes in which the components are separating and therefore suitable not only for gas constituents but also for the solid.

Keywords: thermal exergy, energy balance, deaeration, partial pressure, power resources.

Introduction. The concept of "exergy" was introduced by Rant in 1953 and according to his original formulation, exergy - it is part of the energy, which is equal to the maximum useful work which can make a thermodynamic system in the transition from the initial state to a state of balance with the environment. Exergy like energy, has the additive properties, which simplifies the calculation of exergy of complex systems and processes. In contrast to energy an exergy is lost due to irreversible processes [1]. This exergy property creates preconditions for the thermo economic analysis of processes and systems [2]. 
Exergy balances of technical objects allow to evaluate correctly the effectiveness of the processes occurring into them, to identify ways to improve these processes, making them visual, compelling, with a more accurate representation of the real possibilities of the improvement in these conditions, more precisely, taking into account the specific environmental conditions. In most other methods some comparison operations used for these purposes (for example, changes in entropy of the system), in relation to whom the studied object indicators are estimated. The results of such analysis depend on the right choice of compare operations. Exergy analysis avoids the need for the selection of these operations for existing facilities and for new (planned) to identify the possibility of their implementation in production by comparing the minimum required costs with available resources.

As evidenced by the publication [1...4], an exergy method of thermodynamic analysis is the actual direction of research in the energy and heat engineering, and finds use in chemical engineering and other fields.

The advantage of the exergy method is in the accounting not only the quantity but also the quality of energy flows and multicomponent material flows that characterize the energy balance of any power technology system that puts this method on the first place on their objectivity in comparison with traditional methods of thermodynamic analysis.

Complexity of the exergy analysis devices with multi-component flows, where separation processes such as water solutions occur, is that the main technical effect of the process is shown in two ways: in one case, the major problem is to obtain clean water flow, and in another case to obtain the concentrate flow [4...6]. For those processes, where the main objective is to obtain clean water, an exergy effect is manifested in the increase of the exergy flow (for example, water preparation at the heat and nuclear power plants, desalination) [5, 6]. In processes where the main task is solution thickening the useful effect is in the growing of exergy concentrate (for example, concentration of liquid, including radioactive solutions) [7].

Thus, the exergy balances and analysis of such processes require consideration of not only the traditional in heat engineering concepts exergy as a workable part of reserves of the heat and work energy [1], but physical and chemical component consideration also [2,6]. This in its turn complicates the calculations and compilation of balances, selection of criteria of effectiveness of separation processes in general and the individual stages as well as parts of installations (stages)on which the complex process is usually divided.

A similar situation occurs in devices where the gas impurities from water solutions is released (deaeration) [8].

The aim of the work is to demonstrate the features of the application of exergy analysis method for sorption and desorption processes via example of the deaerator.

Materials and Methods. The widest application the exergy method found at cycle and basic processes analysis at heat and nuclear power plants $[1,2,6]$. The following values are considered during the exergy analysis:

— specific flow exergy of environmental weight, $\mathrm{kJ} / \mathrm{kg}$

$$
e=\left(h-h_{0}\right)-T_{0}\left(s-s_{0}\right)+\frac{w^{2}}{2}+g z
$$

— complete exergy of flow, $\mathrm{kW}$

$$
E=m e,
$$

— exergy of the heat flow, $\mathrm{kW}$

$$
E_{q}=\Phi\left(1-\frac{T_{0}}{T}\right)
$$

where $h, h_{0}$ - enthalpies in this state and in the environment state, respectively, $\mathrm{kJ} / \mathrm{kg}$;

$s, s_{0}$ - entropies in this state and in the state of the environment, respectively, $\mathrm{kJ} /(\mathrm{kg} \mathrm{K})$;

$w$ - flow rate, $\mathrm{m} / \mathrm{s}$; 
$g$ - gravity acceleration, $\mathrm{m} / \mathrm{s}^{2} ;$

$T, T_{0}$ - temperatures in this state and in the environment state, respectively, $\mathrm{K}$;

$\Phi$ - heat flow, kW;

$m$ - environmental weight flow, $\mathrm{kg} / \mathrm{s}$;

$z$ - height (position) above sea level, $\mathrm{m}$.

As follows from these equations concept "environment" has high importance. The "environment" means a certain unchanging "container" whose parameters are saved, regardless of any impact. In power engineering the Earth's atmosphere with the pressure $p_{0}$ and temperature $T_{0}$ is selected as a "container" by default. In case physic and chemical transformations it is necessary to supplement the concept of environment its parameters [1]. Regarding to the cleaning devices, including deaerator, it may be an indication of the states in which the major contaminants are in environment and removed in the device. In this paper, the condition of atmospheric oxygen $\left(\mathrm{O}_{2}\right)$ is accepted as an additional environment parameter. This is the main component that removed in the deaerator and characterized by the molar concentration and the partial pressure of oxygen in the atmosphere. Under this approach for all other flows the calculations were conducted on the equilibrium partial pressures corresponding to the concentration of oxygen in the contacted medium (water). For the calculation of changes in the specific exergy of two separate flows in deaerators (gas environment and deaerated water) it has allowed to use the specific work and its changes in a reversible transition component (oxygen) process into the environment. Value determined in such a way $\left(e_{x}, \mathrm{~J} / \mathrm{kg}\right)$ is called specific sorption exergy and specific desorption exergy of gases:

$$
e_{x}=-R T_{0} \ln \frac{p_{i}}{p_{0 i}},
$$

where $T_{0}$ - environmental temperature, $\mathrm{K}$;

$p_{i}$ - the balanced partial pressure, determined, for example, Henry's law on concentration of an impurity in the water in a given state, bar;

$p_{0 i}$ - partial pressure under environmental conditions, bar.

Analyzing the expression (3), we can conclude that the positive exergy of residual oxygen takes place when the oxygen partial pressure corresponding to a given concentration in water is less than the oxygen partial pressure in the environment. However, possible states (especially steam-gas), when this condition can't be executed, which leads to causing a negative value of the specific exergy (3). Since a negative value of exergy makes no physical sense, this contradiction can be resolved as follows: in such states may get a work in a reversible process of oxygen transition from the state corresponding to the environment, to the parameters of the given state. Thus, the expression module should be used to calculate the exergy gases sorption and desorption (3). Note, that this argument is similar to how the concept of exergy is used in the case of analysis of refrigeration processes that take place at temperatures below ambient temperature, for which formal expression (2) may gives negative values [1,2].

However, exergy of gas components in solution is characterized not only chemical-physical component, but also the thermal component defined by equation (1). Thus, the total exergy of oxygen in water is equal to the sum of:

$$
e_{O_{2}}=e_{t}+e_{x},
$$

where $e_{t}$ - heat component of exergy is determined from the equation (1), provided that the partial pressure of the component in this state is equal to the partial pressure of the component in the environment $\left(p_{i}=p_{0 i}\right)$.

Note, that if you choose for the state of the environment the impurity concentration, for example, in the ocean water that the most suitable for solids dissolved in water, the method of calculation component of exergy sorption and desorption of gases will be another [9].

Often the equation (1) simplify, ignoring the last two terms because of their smallness, and is written as: 


$$
e=\left(h-h_{0}\right)-T_{0}\left(s-s_{0}\right) .
$$

With respect to deaerator it is quite acceptable, but it should not be done for the individual steps of the deaerator, due to the fact that the interacting flows are increased speed. Furthermore, the hydrodynamic interaction of steam and condensate flows typical not only for water, but also for gases dissolved into water and steam. In particular, the gas emission from the water, accompanied by transformations of exergy of sorption and desorption of gases directly related to the hydrodynamic characteristics of the interaction of flows, therefore their account could affect the understanding of exergy transformation.

Results and Discussion. In carrying out the calculations of flows exergy in the deaerator is taken into account that the exergy balance of flow processes may compose by placing data about the state of flows just on the border of the selected balance circuit which is selected as the deaerator in general. Schematically the deaerator flows are presented in Fig. 1. For simplicity deaerator heat exchange with the environment neglected in the future.

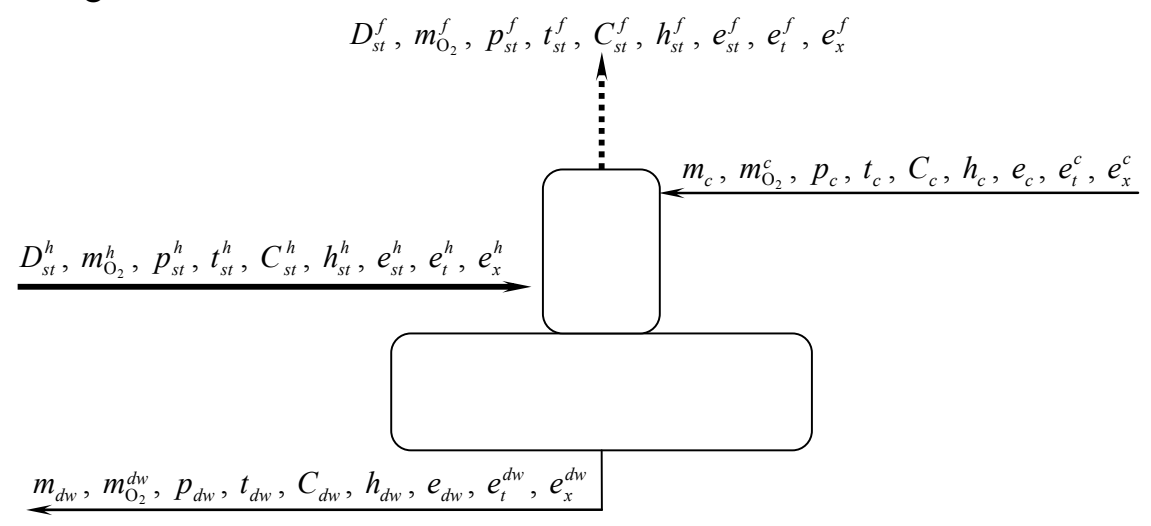

Fig. 1. The balance deaerator scheme: $D_{s t}^{h}, D_{s t}^{f}, m_{c}, m_{d w}$-consumption of heating steam, flash steam, condensate and deaerated water, respectively, $\mathrm{kg} / \mathrm{s} ; m_{\mathrm{O}_{2}}^{h}, m_{\mathrm{O}_{2}}^{f}, m_{\mathrm{O}_{2}}^{c}, m_{\mathrm{O}_{2}}^{d w}$-oxygen consumption for previously mentioned flows, respectively, $\mathrm{kg} / \mathrm{s} ; p_{s t}^{h}, t_{s t}^{h}, p_{s t}^{f}, t_{s t}^{f}, p_{c}, t_{c}, p_{d w}, t_{d w}$ - pressure and temperature of previously mentioned flows, respectively, $\mathrm{MPa},{ }^{\circ} \mathrm{C} ; \mathrm{C}_{s t}^{h}, C_{s t}^{f}, C_{c}, C_{d w}$-oxygen concentration of previously mentioned flows, $\mu \mathrm{g} / \mathrm{kg} ; h_{s t}^{h}, h_{s t}^{f}, h_{c}, h_{d w}$-enthalpy in a given state and in the environment state, respectively,

$\mathrm{kJ} / \mathrm{kg} ; e_{s t}^{h}, e_{s t}^{f}, e_{c}, e_{d w}$ - total specific exergy of mentioned flows, $\mathrm{kJ} / \mathrm{kg} ; e_{t}^{h}, e_{t}^{f}, e_{t}^{c}, e_{t}^{d w}$ - heat component of specific exergy for previously mentioned flows, respectively, $\mathrm{kJ} / \mathrm{kg} ; e_{x}^{h}, e_{x}^{f}, e_{x}^{c}, e_{x}^{d w}$-component of specific exergy of sorption and desorption for previously mentioned flows, respectively, $\mathrm{kJ} / \mathrm{kg}$.

Below are the numerical calculations of deaerator exergy flows data with the following parameters:

— heating steam: $p_{s t}^{h}=0.7 \mathrm{MPa}, t_{s t}^{h}=300^{\circ} \mathrm{C}, h_{s t}^{h}=3059.5 \mathrm{~kJ} / \mathrm{kg}, D_{s t}^{h}=7.5 \mathrm{~kg} / \mathrm{sec}, C_{s t}^{h}=10 \mu \mathrm{g} / \mathrm{kg}$;

— flash steam: $p_{s t}^{f}=0.6 \mathrm{MPa}, t_{s t}^{f}=158.8^{\circ} \mathrm{C}, D_{s t}^{f}=0.294 \mathrm{~kg} / \mathrm{sec}$;

—input condensate: $p_{c}=0.7 \mathrm{MPa}, t_{c}=130{ }^{\circ} \mathrm{C}, m_{c}=140 \mathrm{~kg} / \mathrm{sec}, C_{c}=200 \mu \mathrm{g} / \mathrm{kg}$;

— output condensate (deaerated water): $p_{d w}=0.6 \mathrm{MPa}, t_{d w}=158^{\circ} \mathrm{C}, m_{d w}=147.2 \mathrm{~kg} / \mathrm{sec}, C_{d w}=10 \mu \mathrm{g} / \mathrm{kg}$.

As the environmental parameters in the calculations are accepted $p_{0}=0.1 \mathrm{MPa}, T_{0}=293 \mathrm{~K}$; partial pressure of oxygen in the air $p_{\mathrm{O}_{2} i} \approx 0.21$ bar.

To calculate the specific chemical exergy of oxygen in the heating steam it was calculated the volume fraction of oxygen in steam $\varphi_{\mathrm{O}_{2}}$, assuming that the oxygen mass concentration in steam $C_{s t}^{h}$ known, i.e.

$$
\varphi_{\mathrm{O}_{2}}=\frac{V_{\mathrm{O}_{2}}}{V_{s t}^{h}}=\frac{C_{s t}^{h} \rho_{s t}}{\rho_{\mathrm{O}_{2}}},
$$


and then the partial pressure of oxygen in the heating steam:

$$
p_{\mathrm{O}_{2}}=p_{s t} \varphi_{\mathrm{O}_{2}} \text {. }
$$

Calculation of specific exergy of sorption and desorption of oxygen in the condensate was held in two stages:

- Firstly, it was calculated the balanced oxygen partial pressure $p_{\mathrm{O}_{2}}$ corresponding to the concentration in the condensate:

$$
p_{\mathrm{O}_{2}}=\frac{22,4 \cdot C_{c} \cdot \rho_{\mathrm{H}_{2} \mathrm{O}} \cdot p_{0}}{M_{\mathrm{O}_{2}} \cdot \alpha_{\mathrm{O}_{2}}},
$$

where $C_{c}$ - oxygen concentration in the condensate, $\mathrm{g} / \mathrm{kg}$;

$M_{\mathrm{O}_{2}}$ - oxygen molar mass, $\mathrm{kg} / \mathrm{mol}$;

$\alpha_{\mathrm{O}_{2}}$ - oxygen absorption rate at the reference temperature.

Remark: Eq. (8) is a Henry's Law through the dimensionless absorption coefficient $\alpha_{\mathrm{O}_{2}}$, which facilitates its use in practical deaerators calculations in Power Engineering.

- Secondly, the value of the balanced oxygen partial pressure in the condensate is substituted in the expression (3).

Calculation of the specific exergy of oxygen adsorption and desorption in the deaerated water and flash steam carried out in a similar way.

To analyze and compare the results of all calculations they are summarized in Table 1.

All energy flows and exergy flows are calculated according to found specific flows and corresponding environments consumptions. Flows of water, steam and oxygen were considered separately, and the summary energy flows and flows of exergy are calculated according to additive rule. The calculation results are summarized in Table 2.

Table 1

Specific exergy in deaerator

\begin{tabular}{l|c|c|c|c}
\hline \multicolumn{1}{c|}{ Specific exergy, $\mathrm{kJ} / \mathrm{kg}$} & $\begin{array}{c}\text { Heating } \\
\text { steam }\end{array}$ & $\begin{array}{c}\text { Conden- } \\
\text { sate }\end{array}$ & $\begin{array}{c}\text { Flash } \\
\text { steam }\end{array}$ & $\begin{array}{c}\text { Deaerated } \\
\text { water }\end{array}$ \\
\hline Specific heat exergy of water and steam, $e_{t_{i}}$ & 923.5 & 70.63 & 778.4 & 107.3 \\
\hline The specific heat exergy of oxygen, $e_{t_{i}}^{O_{2}}$ & 90.3 & 18.0 & 42.1 & 48.9 \\
\hline Specific exergy sorption and desorption of oxygen, $e_{x_{i}}^{O_{2}}$ & 1170.8 & 377.6 & 357 & 494.4 \\
\hline Specific summary oxygen exergy, $e_{\Sigma_{i}}^{O_{2}}$ & 1261.1 & 395.6 & 399.1 & 543.3 \\
\hline
\end{tabular}

Table 2

Energetic and exergy flows of deaerator $\left(H_{i}, E_{i}, M W\right)$

\begin{tabular}{l|c|c|c|c}
\hline \multicolumn{1}{c|}{ Energetic and exergy flows, MW } & $\begin{array}{c}\text { Heating } \\
\text { steam }\end{array}$ & Condensate & Flash steam & $\begin{array}{c}\text { Deaerated } \\
\text { water }\end{array}$ \\
\hline Energy flow of water and steam & 22.95 & 76.54 & 0.810 & 98.68 \\
\hline Energy flow of oxygen in the mix & $24.30 \cdot 10^{-9}$ & $3.93 \cdot 10^{-6}$ & $4.56 \cdot 10^{-6}$ & $4.80 \cdot 10^{-6}$ \\
\hline Summary energy flow & 22.95 & 76.54 & 0.810 & 98.68 \\
\hline Exergy flow of water and steam & 6.927 & 9.889 & 0.229 & 15.80 \\
\hline The flow of heat exergy of oxygen & $6.77 \cdot 10^{-9}$ & $0.504 \cdot 10^{-6}$ & $1.12 \cdot 10^{-6}$ & $7.2 \cdot 10^{-8}$ \\
\hline Exergy flow of sorption and desorption of oxygen & $87.8 \cdot 10^{-9}$ & $10.57 \cdot 10^{-6}$ & $9.50 \cdot 10^{-6}$ & $7.27 \cdot 10^{-7}$ \\
\hline Summary exergy flow of oxygen & $94.6 \cdot 10^{-9}$ & $11.08 \cdot 10^{-6}$ & $10.62 \cdot 10^{-6}$ & $7.99 \cdot 10^{-7}$ \\
\hline The total flow of exergy & 6.927 & 9.889 & 0.229 & 15.802 \\
\hline
\end{tabular}


All the data of Table 2 and calculations is conveniently represented as a scheme energy and exergy flows for the deaerator as a whole (Fig. 2). Due to the lack of comparability of the flow scale ( $\sim \mathrm{MW}$ for deaerator as a whole against $\sim \mathrm{W}$ for oxygen exergy) there is impossible to show exergy flow of oxygen in this figure. Therefore, the oxygen flow diagram in the deaerator is represented separately in Fig. 3.

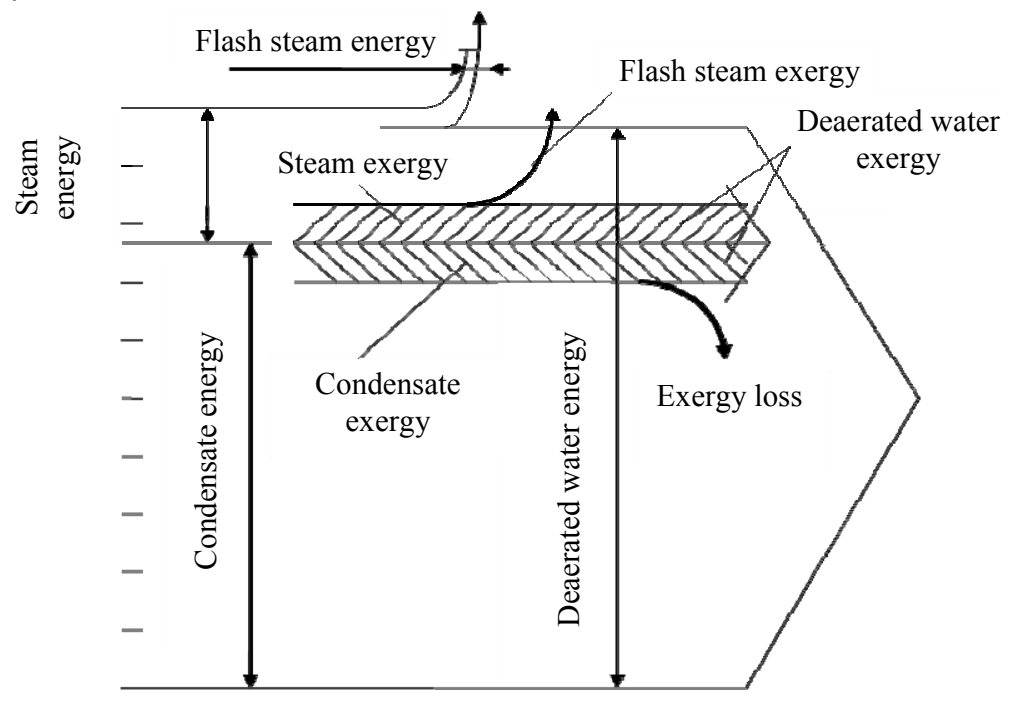

Fig. 2. Scheme of energy and exergy flows in the deaerator

At the input for summary energy flow is obtained $H_{i n}=99.49 \mathrm{MW}$.

At the input for summary exergy flow received $E_{i n}=16.82 \mathrm{MW}$.

Similarly the summary energy flows at the output have been found $H_{\text {out }}=99.49 \mathrm{MW}$, which confirms the acceptance of the conditions of the absence of heat exchange of deaerator with the environment, and summary flow of exergy at output $E_{\text {out }}=16.03 \mathrm{MW}$.

Data on the energy flows at the input and output of the deaerator allowed us to calculate the loss of exergy in the deaerator as a whole:

$$
\Delta E=E_{\text {in }}-E_{\text {out }}=0.79 \mathrm{MW} .
$$

For the example above the oxygen flow exergy at input and output were calculated additionally, accounting for, respectively, $E_{\text {in }}^{O_{2}}=11.17 \mathrm{~W}$ and $E_{\text {out }}^{O_{2}}=11.42 \mathrm{~W}$, and oxygen energy gain in the deaerator were found:

$$
\Delta E^{O_{2}}=E_{\text {out }}^{O_{2}}-E_{\text {in }}^{O_{2}}=0.25 \mathrm{~W} .
$$

Analysis of the data presented in tables and in Fig. 2 and 3, as well as additional data about flows of energy and exergy at the input and output from deaerator, leads to the conclusion that the value of exergy flows which characterizing of transformation of dissolved oxygen in all flows (heating steam, flash steam, condensate and deaerated water) is negligible compared to the heat component of the flows exergy, and especially with the energy flow value. Therefore, we can assert that the main purpose of the deaerator associated with the release of oxygen, for heat deaeration is achieved at great energy and exergy consumptions, conversion of which is directed mainly on heat transfer and effective in generally. Therefore, from this standpoint deaerator serves as an effective heater and that its function is very successful, but the technological function of the deaerator to remove oxygen is far from perfect. For example, in work [10], the authors examined the dimensionless characteristics of exergy transformations in deaerator that can be used as exergy efficiency. 


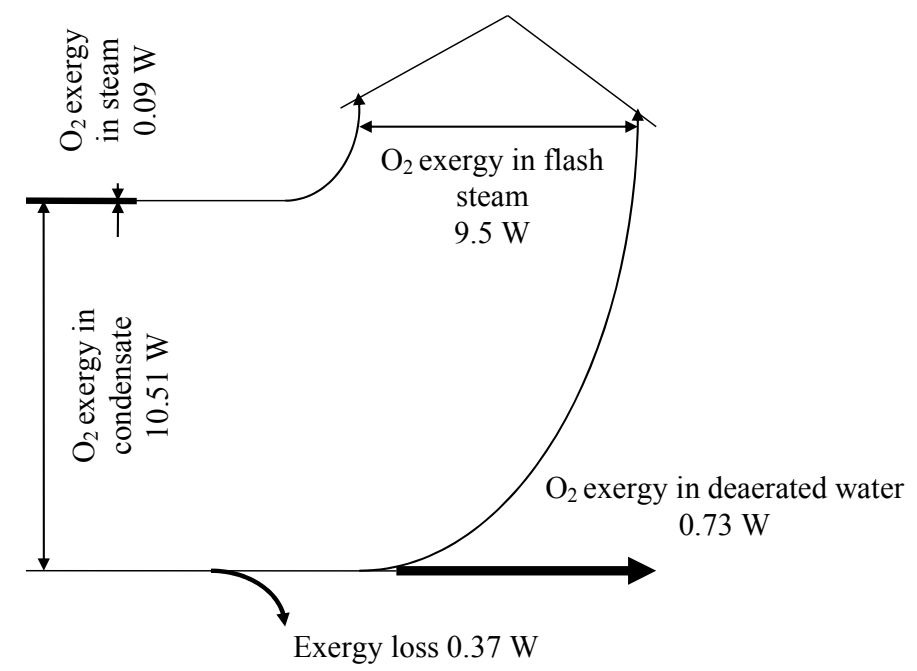

Fig. 3. Exergy flows of oxygen sorption and desorption in the deaerator

In particular, the flow diagram in Fig. 3 shows that one of the obvious ways to improve processes in the deaerator is associated with recycling, rational use of power resources of flash steam that is typically implemented at the heat and nuclear power plants.

Conclusions. According to the results of the study the following can be concluded:

- exergy analysis of processes taking place in the deaerator has shown high efficiency of deaerator as a heat exchanger and a low efficiency as a mass exchanger;

- heat exergy in deaerators flows by several orders higher than exergy flows of sorption and desorption of gases, which makes them completely incompatible;

- as the value of the transformed energy of oxygen in the deaerator is small, so even very small hydrodynamic perturbations can affect on the effectiveness of deaeration, that can explain the appearance of new deaeration systems with the use of centrifugal and other effects;

- considered method allows evaluating the physical and technological processes in which the components are separating and therefore this method suitable not only for the gas components, but also to solids solutions;

- exergy method of any physic and technological process and energy system allows optimizing it by the variation structure of parameters in order to minimize capital and operating costs at the appropriate resource and technological limits to ensure the protection of the environment.

\section{Література}

1. Шаргут, Я. Эксергия / Я. Шаргут, Р. Петела; пер. с пол.: Ю.И. Батурина, Д.Ф. Стржижовского; под ред. В.М. Бродянского. — М.: Энергия, 1968. — 279 с.

2. Ahern, J.E. The exergy method of energy systems analysis / J.E. Ahern. — New York: Wiley, 1980 — 295 p.

3. Rant, Z. Exergie, ein neues Wort für „technische Arbeitsfähigkeit“ / Z. Rant // Forschung auf dem Gebiete des Ingenieurwesens. - 1956. - Vol. 22. - PP. 36 - 37.

4. Амерханов, Р.А. Эксегроэкономическая оптимизация теплонасосных систем / Р.А. Амерханов // Энергосбережение и водоподготовка. — 2003. - № 2. - С. $65-67$.

5. Exergy analysis and design optimization for aerospace vehicles and systems / ed. by J.A. Camberos, D.J. Moorhouse. - Reston: American Institute of Aeronautics and Astronautics, 2011. — 632 p.

6. Kotas, T.J. The exergy method of thermal plant analysis / T.J. Kotas. — London; Boston: Butterworths, 1985. - $296 \mathrm{p}$.

7. Li, M. Exergy transfer analysis of convection heat transfer / M. Li, H. Chen // Heat Transfer-Asian Research. - 2007. — Vol. 36, Issue 2. - PP. 66 - 73.

8. Термодинамика, энергетическая эффективность и экология / В.С. Белоусов, Г.П. Ясников, А.В. Островская и др.; под ред. Г.П. Ясникова. — Екатеринбург: Полиграфист, 1999. — 204 с. 
9. Кочаров, Р.Г. Теоретические основы обратного осмоса / Р.Г. Кочаров. - М: РХТУ им. Д.И. Менделеева, 2007. - 143 с.

10. Кардасевич, О.А. Эксергетический баланс и эффективность химико-технологических процессов на примере расчета деаэратора / О.А. Кардасевич, А.С. Грицаенко // Перспективи майбутнього та реалії сьогодення в технологіях водопідготовки: матер. міжнарод. наук.-практ. конф., 18-19 листопада 2015 р., Київ, Україна. — К.: «Центр учбової літератури», 2015. — С. 90-92.

\section{References}

1. Szargut, J., \& Petela, R. (1965). Egzergia. Warszawa: Wydawnictwo Naukowo-Techniczne.

2. Ahern, J.E. (1980). The Exergy Method of Energy Systems Analysis. New York: Wiley.

3. Rant, Z. (1956). Exergie, ein neues Wort für „technische Arbeitsfähigkeit“. Forschung auf dem Gebiete des Ingenieurwesens, 22, 36-37.

4. Amerkhanov, R.A. (2003). Exergoeconomic optimization of heat pumping systems. Energysaving and Watertreatment, 2, $65-67$.

5. Camberos, J.A., \& Moorhouse, D.J. (Eds.). (2011). Exergy Analysis and Design Optimization for Aerospace Vehicles and Systems. Reston: American Institute of Aeronautics and Astronautics.

6. Kotas, T.J. (1985). The Exergy Method of Thermal Plant Analysis. London; Boston: Butterworths.

7. Li, M., \& Chen, H. (2007). Exergy transfer analysis of convection heat transfer. Heat Transfer-Asian Research, 36(2), 66 - 73. DOI:10.1002/htj.20146

8. Belousov, V.S., Yasnikov, G.P., Ostrovskaya, A.V., Evplanov, A.I., \& Pavlyuk, E.Yu. (1999). Thermodynamics, Energy Efficiency, and Ecology. Yekaterinburg: Poligrafist.

9. Kocharov, R.G. (2007). Theoretical Principles of Reverse Osmosis. Moscow: Dmitry Mendeleev University of Chemical Technology of Russia.

10. Kardasevich, O.A., Hrytsayenko, A.S. (2015). Exergy balance and efficiency of the chemical technology processes via example of deaerator. In Proceedings of International Scientific and Practical Conference on Future Prospects and Today's Realities of Water Treatment Technologies (pp. 90-92). Kyiv: Centr Uchbovoj Literatury. 